J. Biosci., Vol. 3 Number 2, June 1981, pp. 157-166. (C) Printed in India.

\title{
Transport of retinol in the duck plasma
}

\author{
B. SRIDHARA RAO, N. APPAJI RAO and H. R. CAMA
}

Department of Biochemistry, Indian Institute of Science, Bangalore 560012

MS received 4 February 1981

\begin{abstract}
Retinol-binding protein and prealbumin were isolated from duck plasma by chromatography on DEAE-cellulose-and DEAE-Sephadex A-50, gel filtration on Sephadex G100 and preparative Polyacrylamide gel electrophoresis. The molecular weights of the retinolbinding protein-prealbumin complex, prealbumin and retinol-binding protein were found to be 75,000, 55,0000 and 20,000, respectively. On sodium dodecyl sulphate Polyacrylamide gel electrophoresis, prealbumin dissociated into identical subunits exhibiting a molecular weight of 13,500. Retinol-binding protein exhibited microheterogeneity on electrophoresis, whereas prealbumin moved as a single band unlike the multiple bands observed in chicken and rat. The ultraviolet and fluorescence spectra of the two proteins were similar to those isolated from other species. No carbohydrate moiety was detected in either retinol-binding protein or prealbumin. Duck retinol-binding protein and prealbumin showed cross-reactivity with their counterparts in chicken but differed immunologically from those of goat and man. Retinolbinding protein and prealbumin could be dissociated at low ionic strength, in $2 \mathrm{M}$ urea, by CMsephadex chromatography or on preparative electrophoresis. Although the transport of retinol in duck plasma is mediated by carrier proteins as in other species, it is distinguished by the absence of microheterogeneity in prealbumin and of an apo-retinol-binding protein form that could be transported in the plasma.
\end{abstract}

Keywords. Retinol; prealbumin; plasma transport; duck.

\section{Introduction}

It is well established that retinol is transported in human plasma bound to a specific retinol-binding protein (Kanai et al., 1968). The retinol-binding protein forms a tight complex with plasma prealbumin and normally circulates as an equimolar complex with it (Peterson and Berggard, 1971; Raz and Goodman, 1969; Peterson, 1971). A similar retinol-transport system has been reported in several other species (Muto et al., 1973; Peterson et al., 1974; Abe et al., 1975; Bhat et al., 1977) and evidence has been presented for the identity of the plasma and egg-yolk retinolbinding protein-prealbumin complexes in the case of chicken (Heller, 1976). In pursuance of earlier studies in our laboratory on the mode of transport of retinol for embryonic development in duck (Sreekrishna and Cama, 1978), the plasma transport system in duck was characterized by the isolation of retinol-binding protein and prealbumin. 


\section{Materials and methods}

\section{Materials}

Blood was collected after decapitation of the ducks and was allowed to clot. The clear supernatant serum was collected and processed immediately. DEAEcellulose (0.9 milliequivalents/g), Sephadex G-100, bovine serum albumin, ovalbumin, cytochrome $\mathrm{C}, \alpha$-chymotrypsinogen, hexokinase, acrylamide, $\mathrm{N}, \mathrm{N}, \mathrm{N}^{\prime}, \mathrm{N}^{\prime}$-tetramethylene diamine, ammonium persulphate, bromophenol blue, Coomassie Brilliant Blue, Tris (hydroxymethylarninomethane) and glycine were all purchased from Sigma Chemical Company, St. Louis, Missouri, USA. Agar and Freund's complete adjuvant were obtained from Difco Lab., Detroit, Michigan, USA. All other chemicals were of reagent grade.

\section{Methods}

Protein-bound retinol was monitored by measuring the relative fluorescence intensity $(F)$ at $470 \mathrm{~nm}$ upon excitation at $330 \mathrm{~nm}$ in a Perkin Elmer spectrofluorometer (Model 203). Protein was estimated by the method of Lowry et al. (1951) using crystalline bovine serum albumin as the standard. Analytical Polyacrylamide gel $(7.5 \% \mathrm{w} / \mathrm{v})$ electrophoresis was performed by the method of Davis (1964). Glycoprotein staining was performed according to the method of Segrest and Jackson (1972). Preparative electrophoresis was carried out using cylindrical gels $(1.2 \times 9$ $\mathrm{cm}$ ) with $0.5-1.0 \mathrm{ml}$ of spacer gel. After electrophoresis, the gel was examined under an ultraviolet lamp for fluorescence of protein-bound retinol. The fluorescent zone was sliced and retinol-binding protein eluted from the gel slice by electro-elution or by homogenization and extraction with $2 \mathrm{OmM}$ Tris- $\mathrm{HCl}$ buffer, pH 7.6 containing $0.2 \mathrm{M} \mathrm{NaCl}$. The gel particles were removed either by centrifugation at $12,000 \mathrm{~g}$ for $10 \mathrm{~min}$ or by filtration through a Whatman No. 1 filter paper. For prealbumin, the region of the gel between the fluorescent zone and the marker dye was cut into thin slices and the protein eluted from each slice as described above. The single protein peak obtained with a mobility intermediate between the marker dye and albumin was designated as prealbumin. Occassionally, the prealbumin band was identified by comparison with a duplicate gel stained with Coomassie Brilliant Blue G.

Determination of molecular weight. Molecular weights were determined by gel filtration using a Sephadex G-100 column calibrated with cytochrome C, $\alpha$-chymotrypsinogen, ovalbumin, bovine serum albumin and hexokinase according to the method of Whitaker (1963). Sodium dodecyl sulphate Polyacrylamide gel electrophoresis was carried out according to the method of Laemmli (1970) using bovine serum albumin, ovalbumin and cytochrome $\mathrm{C}$ as standards.

Preparation of antibodies. Rabbits (Institute strain) were immunized by intradermal injection, once a week, with $100 \mu \mathrm{g}$ of retinol-binding protein or prealbumin in phosphate buffered saline emulsified in Freund's complete adjuvant. After three immunizations, a booster injection of $300 \mu \mathrm{g}$ of protein in phosphate buffered saline was given and after six days the animals were bled through the marginal ear vein, the serum prepared and stored frozen. Immuno-double diffusion was carried out according to the method of Ouchterlony (1967). 
Binding experiments. The binding of thyroxine and retinol-binding protein to prealbumin was monitored by the quenching of the protein fluorescence of prealbumin. The control employed in studying thyroxine binding was N-acetyl-L. tryptophanamide having the same absorbance as that of prealbumin. When the binding of retinol-binding protein was being monitored, the increase in the fluorescence upon addition of retinol-binding protein to buffer alone was deducted from the experiment.

The dissociation-association experiments were carried out by gel filtration on a Sephadex G-100 column $(0.9 \times 38 \mathrm{~cm})$.

Preparation of apo-retinol-binding protein. Apo-retinol-binding protein was prepared by shaking retinol-binding protein solution with an equal volume of diethyl ether at a rate of $75 \pm 5$ strokes per min in the dark at $25 \pm 2^{\circ} \mathrm{C}$ for $6 \mathrm{~h}$, under nitrogen in a stoppered test tube.

\section{Results}

\section{Purification}

Duck serum was applied onto a DEAE-cellulose column and the bound protein were eluted by a linear gradient of sodium chloride concentration from 0.1 to $0.35 \mathrm{M}$. Protein-bound retinol eluted on the descending side of the main protein peak (figure 1). The fluorescent fractions were pooled, dialyzed against $0.1 \mathrm{M}$

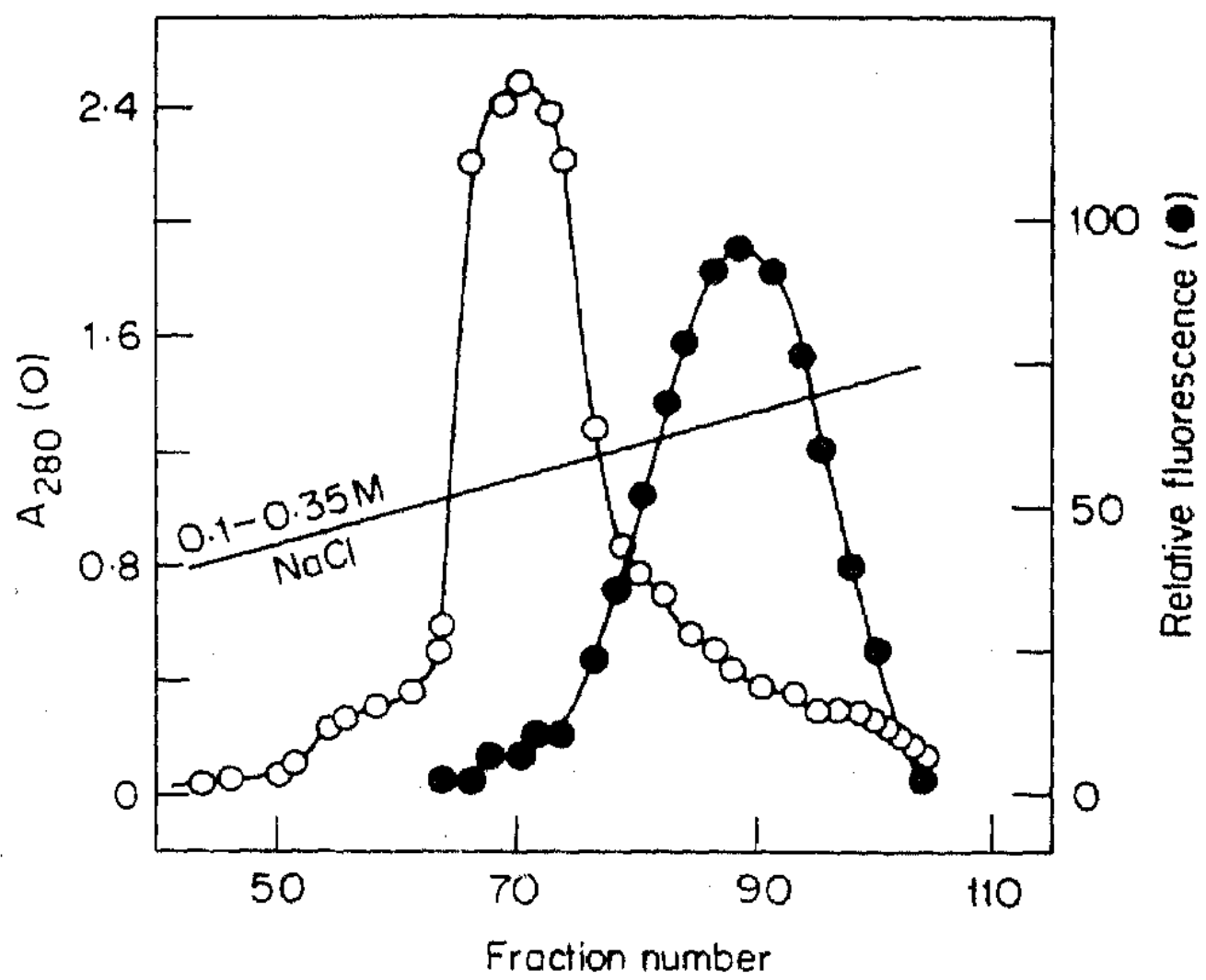

Figure 1. DEAE-cellulose chromatography of duck serum. Serum (100ml) dialyzed against $20 \mathrm{mM}$ Tris- $\mathrm{HCl}$ buffer $\mathrm{pH} 7.6$, containing $0,1 \mathrm{M} \mathrm{NaCl}$ was loaded onto a column $(2 \times 50 \mathrm{~cm})$ of DEAE-cellulose equilibrated with the same buffer. Bound proteins were eluted with a linear gradient of sodium chloride from 0.1 to $0.35 \mathrm{M}$, Fractions of $10 \mathrm{ml}$ were collected at a flow rate of $30 ' \mathrm{ml} / \mathrm{h}$. Fluorescent fractions were pooled. 
sodium acetate buffer, $\mathrm{pH} 5.4$, and subjected to a second ion exchange chromatography on DEAE-Sephadex. Elution was carried out by a linear gradient of 0.1 to $0.5 \mathrm{M}$ sodium acetate. Sephadex G-100 gel filtration of the fluorescent fraction from the above step resulted in the elution of two protein peaks (figure 2). The

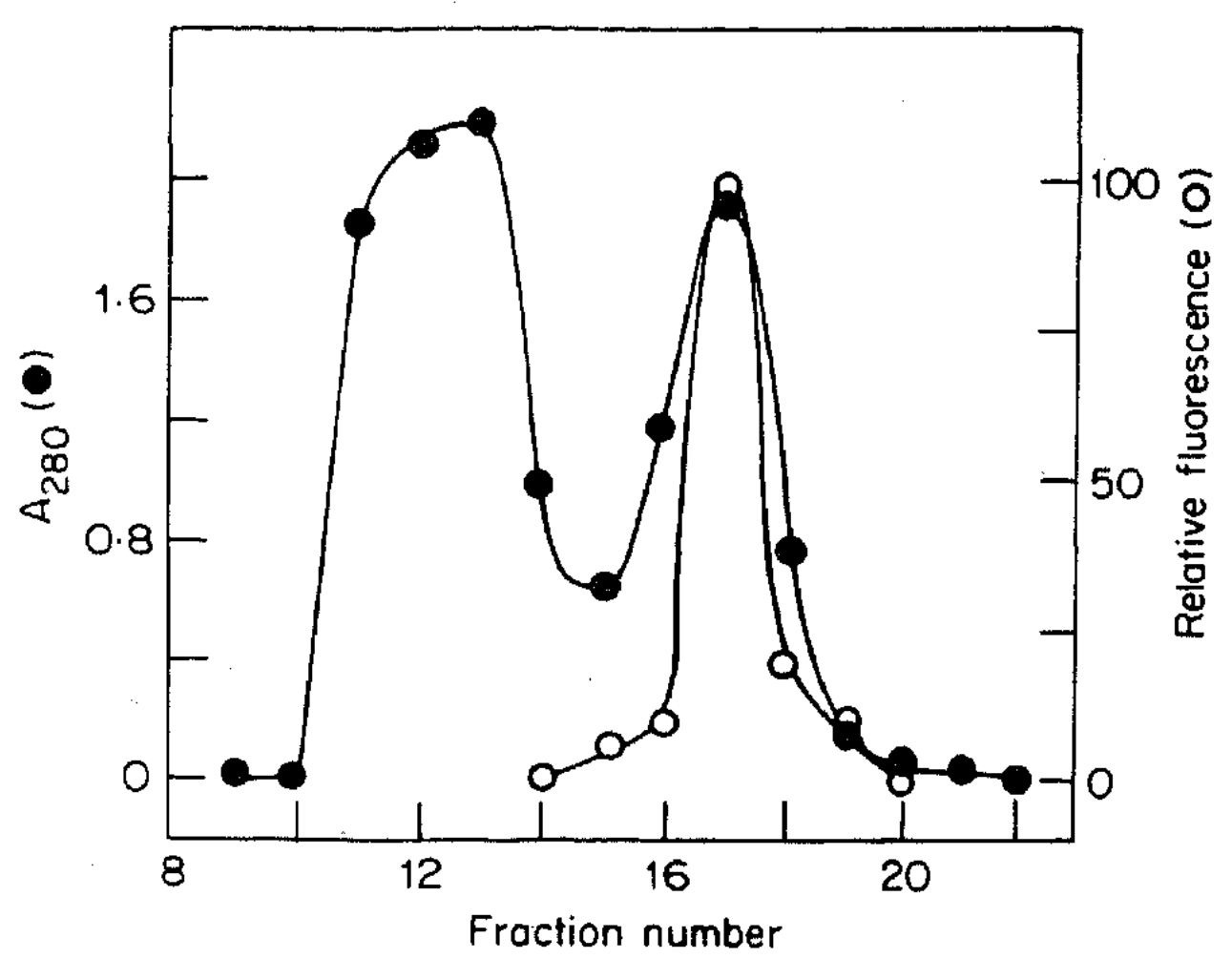

Figure 2. Sephadex G-100 gel filtration. The fluorescent fraction from the ion exchange chromatography was concentrated, dialyzed against $20 \mathrm{mM}$ Tris-HCl buffer $\mathrm{pH}$ 7.6, containing $0.2 \mathrm{M} \mathrm{NaCl}$ and applied on a column $(2 \times 44 \mathrm{~cm})$ of Sephadex G-100 equilibrated with the same buffer. Fractions of $3 \mathrm{ml}$ were collected at a flow rate of $12 \mathrm{ml} / \mathrm{h}$.

fluorescence was associated with the second peak. These fractions were pooled, concentrated and subjected to preparative polacrylamide gel electrophoresis. Localization of proteins and elution was carried out as described under Methods. Retinol-binding protein, after this step, was occasionally found to be contaminated with traces of albumin and hence was further purified by gel filtration on Sephadex G-100. The prealbumin obtained was pure and did not require further purification. Retinol-binding protein and prealbumin could be reassociated to form a complex (see below).

\section{Electrophoretic pattern}

On analytical polacrylamide gel electrophoresis, retinol-binding protein exhibited two closely spaced bands exhibiting greenish blue fluorescence characteristic of retinol. Sodium dodecyl sulphate-polyacrylamide gel electrophoresis indicated that the two species had the same molecular weight $\left(M_{r} 20,000\right)$. In analogy with 
the existing nomenclature, the fast and slow moving bands were designated as holof-retinol-binding protein and holo ${ }_{\mathrm{s}}$-retinol-binding protein, respectively. Evidently, the amount of the fast moving spcies is much higher. Prealbumin exhibited a single band, with a much faster mobility, trailing just behind the marker dye (figure 3).
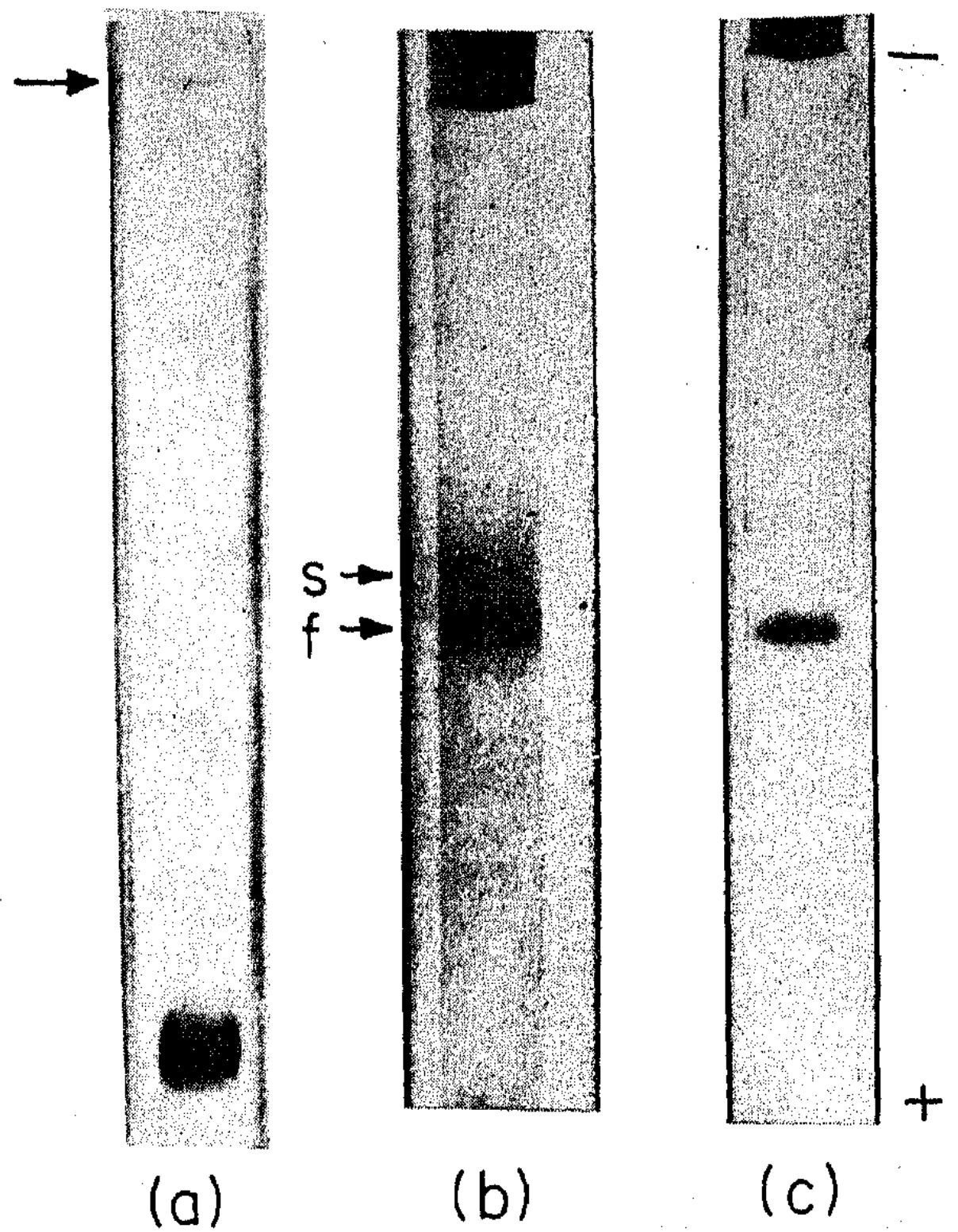

Figure 3. Electrophoretic pattern on $7.5 \%$ Polyacrylamide gels in Tris-glycine buffer at $\mathrm{pH} 8.3$ (a) Prealbumin (b) Retinol-binding protein. $\mathrm{s}$ and $\mathrm{f}$ indicate holo $\mathrm{s}_{\mathrm{s}}$ and holof-retinolbinding proteins, respectively, (c) Holof-retinol-binding protein separated by preparative Polyacrylamide gel electrophoresis.

\section{Molecular weights}

The molecular weights of complexed retinol-binding protein, prealbumin and retinol-binding protein, as estimated by gel filtration, were 75,000, 55,000 and 20,000 , respectively. On sodium dodecyl sulphate Polyacrylamide gel electrophoresis in the presence of 2-mercaptoethanol, retinol-binding protein exhibited a molecular weight of 20,000 while prealbumin dissociated into subunits of molecular weight, 13,500 . 


\section{Spectroscopic properties}

Retinol-binding protein exhibits two absorption maxima in the ultraviolet region, one at $280 \mathrm{~nm}$ and the other at $330 \mathrm{~nm}$. The retinol-binding protein-prealbumin complex shows only a slight absorbance at $330 \mathrm{~nm}$. The ratio of the absorbance at $280 \mathrm{~nm}$ to $330 \mathrm{~nm}$ was found to be 1.2 in the case of retinol-binding protein and 3.1 in the case of the retinol-binding protein-prealbumin complex. The fluorescence spectra of free as well as complexed retinol-binding protein exhibited two excitation maxima, one at $280 \mathrm{~nm}$ and the other at $330 \mathrm{~nm}$ and two emission maxima, one at $330 \mathrm{~nm}$ and the other at $470 \mathrm{~nm}$. $\mathrm{HoIo}_{\mathrm{s}}-$ and holof-retinol-binding proteins were both fluorescent and their fluorescence spectra were similar and overlapping.

Glycoprotein staining was found to be negative for retinol-binding protein as well as prealbumin.

The addition of retinol-binding protein or L-thyroxine to prealbumin quenched the protein fluorescence indicating that both L-thyroxine and retinol-binding protein could bind prealbumin (figure 4). Retinol-binding protein from which retinol was extracted by diethylether was not able to bind prealbumin.

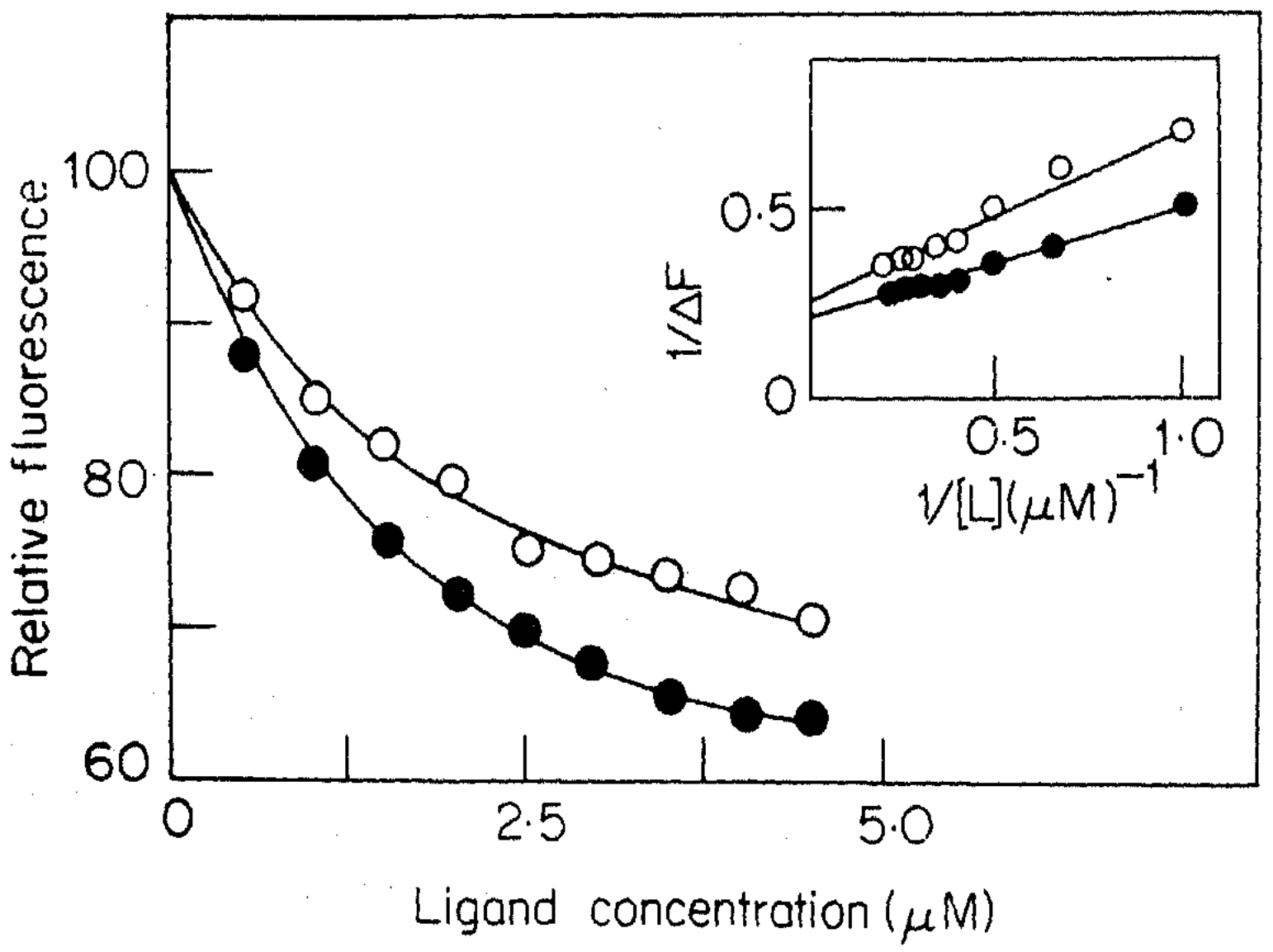

Figure 4. Quenching of the fluorescence of prealbumin by thyroxine and retinol-binding protein. Excitation and emission were set at $280 \mathrm{~nm}$ and $340 \mathrm{~nm}$, respectively To $1 \mu \mathrm{M}$ solution of prealbumin in $20 \mathrm{mM}$ Tris- $\mathrm{HCl}$ buffer $\mathrm{pH} 7.6$ containing $0.2 \mathrm{M} \mathrm{NaCl}$, aliquots of retinol-binding protein in the same buffer or L-thyroxine in $10 \mathrm{mM} \mathrm{NaOH}$ were added. During titration with retinol-binding protein $(\mathrm{O})$, the increase in fluorescence of the buffer alone on the addition of retinol-binding protein was deducted from the experiment. In the case of the titration with thyroxine ( ) $\mathrm{N}$-acetyl-L-tryptophanamide solution having the same absorbance as that of prealbumin was employed as blank. $\Delta F$ : Change in fluorescence. The $\Delta F_{\max }^{\prime}$ obtained was 45 for thyroxine and 30 for retinol-binding protein 


\section{Dissociation and association}

The effects of various factors on the stability of the retinol-binding protein-prealbumin complex were tested. When buffers of various ionic strengths were tested, it was found that a low ionic strength buffer i.e., $2 \mathrm{mM}$ Tris- $\mathrm{HCl}, \mathrm{pH} 7.6$, could completely dissociate the complex. The complex was found to be less susceptible to changes in $\mathrm{pH}$ in the range of 8 to 3 . A negligible amount of retinolbinding protein was found to be dissociated at $\mathrm{pH}$ 3.0. Another effective method of dissociation was chromatography on CM-Sephadex at $\mathrm{pH} 5.4$, when the prealbumin eluted earlier than retinol-binding protein (figure 5). The presence of $2 \mathrm{M}$ urea in the buffer could also bring about dissociation.

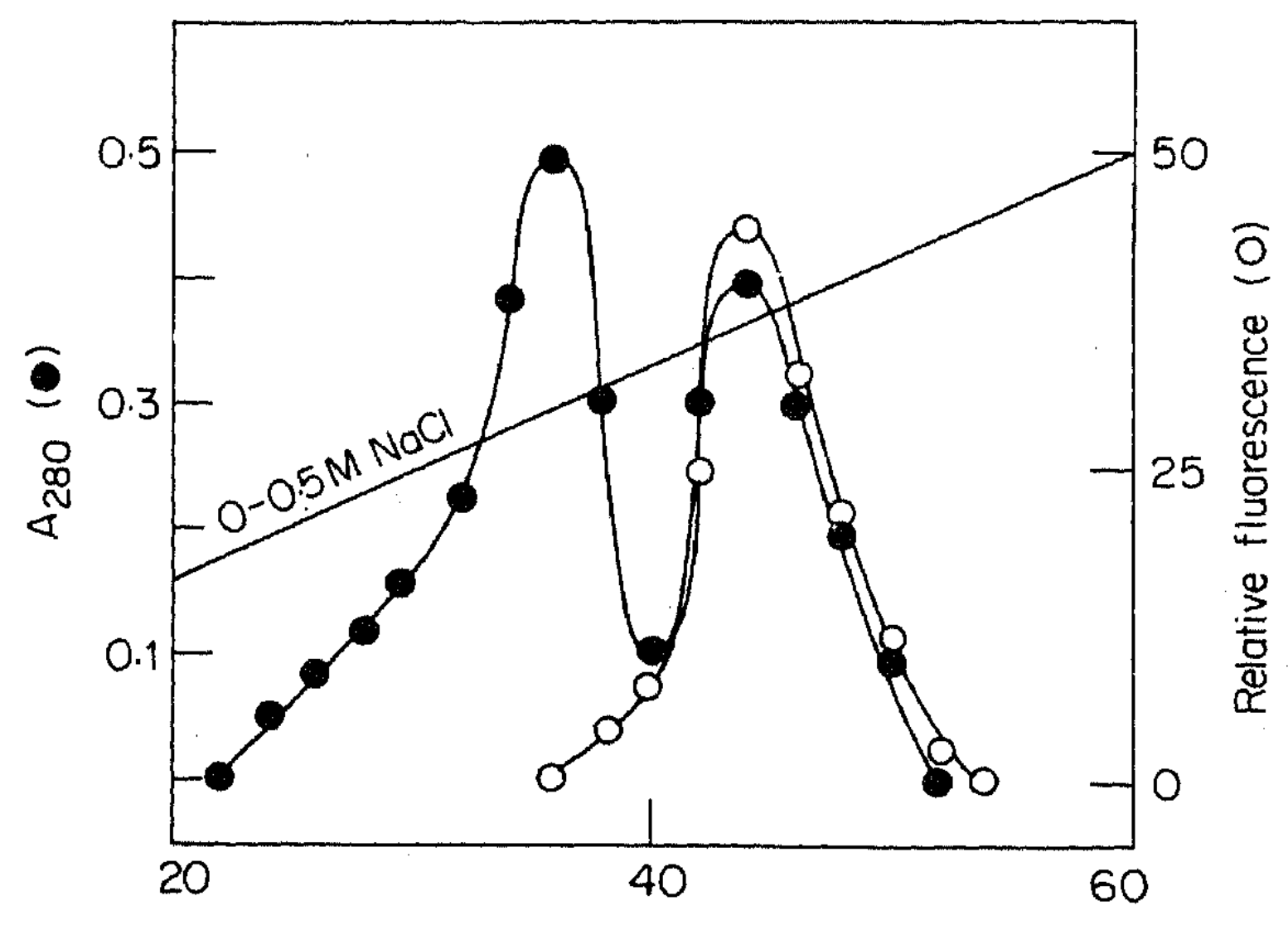

Fraction number

Figure 5. Dissociation of retinol-binding protein-prealbumin complex by CM-Sephadex chromatography. The complexed retinol-binding protein was dialyzed against $50 \mathrm{mM}$ sodium acetate buffer, pH 5.4 and applied onto a column $(1.4 \times 49 \mathrm{~cm})$ of CM-Sephadex equilibrated with the same buffer. Elution was carried out with a linear gradient of $\mathrm{NaCl}$ from 0 to $0.5 \mathrm{M}$. Fractions of $5 \mathrm{ml}$ were collected at a flow rate of $30 \mathrm{ml} / \mathrm{h}$. Peak I was found to be prealbumin and peak II, retinol-binding protein by Polyacrylamide gel electrophoresis.

The dissociation brought about by any of the above methods (including electrophoresis) was completely reversible. When retinol-binding protein and prealbumin were mixed and applied on a Sephadex G-100 column, the elution profile showed a shift of retinol fluorescence to an elution volume corresponding to a molecular weight of 75,000. No association was observed when prealbumin and apo-retinolbinding protein were applied on the column. 


\section{Immunological cross-reactivity}

Ouchterlony immuno-double diffusion studies showed that duck retinol-binding protein and prealbumin exhibited strong cross-reactivity with their counterparts in chicken but did not show any cross reactivity with those of heterologous species like man and goat.

\section{Discussion}

In aggreement with the results obtained from other animal species, the transport of retinol in duck plasma is mediated by a retinol-binding protein-prealbumin complex. The physico-chemical properties of duck retinol-binding protein and prealbumin compare with those from other sources to some extent.

Duck retinol-binding protein showed microheterogeneity upon electrophoresis exhibiting a slow and a fast moving species. Abe et al. (1975) found chicken retinol-binding protein to be devoid of microheterogeneity while others (Kopelman et al., 1976) reported to the contrary. We found, in the case of duck, two closely spaced bands of holo-retinol-binding protein but not of the apo-retinol-binding protein.

The $\mathrm{A}_{280}: \mathrm{A}_{330}$ ratio of the duck retinol-binding protein is lower than that obtained in goat (Sreekrishna and Cama, 1979) and canine (Muto et al., 1973) sources and agree well with the values reported in chicken (Heller, 1976).

An important observation in this study was that duck prealbumin did not exhibit microheterogeneity while that from other sources like chicken (Bhat et al., 1977) exhibited multiple bands on electrophoresis. Another major difference between the duck apo-retinol-binding protein and that isolated from other species (Rask et al., 1971) was its inability to bind prealbumin.

These results, while highlighting the universality of the carrier-mediated retinoltransport mechanism, emphasize that. major differences exist in the physicochemical and immunological properties of these proteins from several species.

\section{Acknowledgements}

The financial support from the University Grants Commission, New Delhi, is gratefully acknowledged. The authors wish to thank Mr. C. Venkateshan for his painstaking help in the preparation of the manuscript.

\section{References}

Abe, T., Muto, Y. and Hosoya, N. (1975) J. Lipid Res., 16, 200.

Bhat, M. K., Sreekrishna, K. and Cama, H. R. (1977) Indian J. Biochem. Biophys., 14,125.

Davis, B. J. (1964) Ann. N. Y. Acad. Sci., 121, 321.

Heller, J. (1976) Develop. Biol, 51, 1.

Kanai, M., Raz, A. and Goodman, D. S. (1968) J. Clin. Invest., 47, 2025.

Kopelman, M., Mokady, S. and Cogan, U. (1976) Biochim. Biophys. Acta, 439,442.

Laemmli, U. K. (1970) Nature (London), 227, 680.

Lowry, O. H., Rosebrough, N. J., Farr, A. L. and Randall, R. J. (1951)J. Biol. Chem., 193, 265. 
Muto, Y., Smith, F. R. and Goodman, D. S. (1973) J. Lipid. Res., 14, 525.

Ouchterlony, O. (1967) in Handbook of Experimental Immunology ed. D. M. Weir (Oxford: Blackwell Publication) p. 655.

Peterson, P. A. (1971)J. Biol. Chem., 246, 34.

Peterson, P. A. and Berggard, I. (1971)J. Biol. Chem.., 246, 25.

Peterson, P. A., Nilsson, S. F., Ostberg, L., Rask, L. and Vahlquist, A. (1974) Vitam. Horm., $32,181$.

Rask, L., Vahlquist, A. and Peterson, P. A. (1971)J, Biol. Chem., 246, 6638.

Raz, A. and Goodman, D. S. (1969)J. Biol. Chem., 244, 3230.

Segrest, J. P. and Jackson, R. L. (1972) Methods Enzymol, Part B 28, 57.

Sreekrishna, K. and Cama, H. R. (1978) Indian J. Biochem. Biophys., 15, 255.

Sreekrishna, K. and Cama, H. R. (1979) Biochem. Biophys. Acta, 581, 136.

Whitaker, J. R. (1963) Anal. Chem., 35, 1950. 